\title{
Overview of catch history, historic abundance and distribution of right whales in the western North Atlantic and in Cintra Bay, West Africa
}

\author{
RANDALL R. REEVES \\ Okapi Wildlife Associates, 27 Chandler Lane, Hudson, Quebec, Canada JOP 1 HO \\ Contact e-mail: rrreeves@total.net
}

\begin{abstract}
The catch history of the North Atlantic right whales (Eubalaena glacialis) in the western North Atlantic has been studied in a series of projects. Data from European archives on early Basque whaling, centred in the Strait of Belle Isle, showed that there were at least a few thousand right whales in the northern part of the range in the sixteenth century. Data from shore whaling in the eastern United States supplemented by British customs data indicated that there were still more than a thousand right whales in the southern part of the range (i.e. south from Nova Scotia) in the late seventeenth century. Right whales were depleted throughout the western North Atlantic by the middle of the eighteenth century, but small shore whaling enterprises persisted in some areas and pelagic whalers continued to kill right whales opportunistically. An increase in alongshore whaling occurred at Long Island (New York) beginning in the 1850s and in North and South Carolina, Georgia and northern Florida in the 1870 s-1880s. By the start of the twentieth century only a few crews of shore whalers remained active in Long Island and North Carolina, and their whaling efforts were desultory. All evidence points to stock depletion as the primary reason for the demise of organised whaling for right whales in eastern North America. Recent sightings indicate that some right whales travel from the Bay of Fundy and Scotian Shelf far to the north and east, at least occasionally reaching the historic Cape Farewell Ground. Areas known to have been used regularly by right whales in the past (e.g. Gulf of St Lawrence, Delaware Bay) are now visited seasonally by only a few individuals. Recent surveys of Cintra Bay, a historic right whale wintering ground in the eastern North Atlantic, provided no evidence of continued use by right whales.
\end{abstract}

KEYWORDS: RIGHT WHALES; NORTH ATLANTIC; WHALING-HISTORICAL; ABUNDANCE ESTIMATE; DISTRIBUTION

\section{INTRODUCTION}

At the IWC workshop on right whales in June 1983, three papers (Aguilar, 1986; Reeves and Mitchell, 1986a; b) were presented concerning the catch history of North Atlantic right whales (Eubalaena glacialis) and several other papers contained relevant data (Brown, 1986; Cumbaa, 1986; Mead, 1986; Mitchell et al., 1986). Additional reports on right whale catch history have been completed since then (Reeves and Barto, 1985; Reeves and Mitchell, 1988; 1990; Reeves, 1991; Reeves et al., 1992; 1999). The present paper summarises the state of knowledge on the catch history of right whales in the western North Atlantic, and identifies work that remains to be completed. Studies of catch history have two primary objectives: estimation of historic abundance and identification of areas that might still be used by right whales.

\section{ABUNDANCE ESTIMATION}

Aguilar (1986) refrained from attempting to estimate the initial abundance of right whales in the western North Atlantic from Basque whaling returns, citing uncertainties about the proportion of bowheads (Balaena mysticetus) in the catch and the effects of density-dependence. Gaskin (1991) used Aguilar's (1986) data to estimate abundance in 1530 , reasoning that if the Basque whalers secured about 200 right whales per year during the peak whaling decades at Red Bay (Labrador), 'with perhaps one third of struck-and-lost-animals dying (sic)', then the cumulative catch could have been as high as 21,000 over the period 1530-1600. He concluded that the initial population size was in the order of 12,000-15,000 right whales. The US 'recovery plan' for North Atlantic right whales (NMFS, 1991) assumed a pre-exploitation population size of at least 10,000 but provided no explanation of why this number was chosen.
Schevill et al. (1986) compared their recent observations in Cape Cod waters with Allen's (1916) compilation of newspaper and other accounts from the late 1600s-early 1700 s, and made the somewhat provocative suggestion that 'the population of right whales passing near Cape Cod is at worst only slightly smaller now than it was in the 17th century'. After a crude preliminary analysis of oil and baleen imports from the North American colonies to London between 1696-1725, Reeves (1991) concluded that 'right whales are far less abundant in the western North Atlantic today than they were in the 17th century'. A less crude, but still preliminary, analysis of the same data suggested that well over 1,000 right whales were present in coastal waters of the eastern United States in the 1680s, at the beginning of an intense episode of shore whaling (Reeves et al., 1992). The British customs data demonstrate that Schevill et al.'s (1986) comparison of sighting rates in the twentieth century with Allen's (1916) miscellaneous compilation of records from the late seventeenth and early eighteenth centuries was a questionable approach to assessing the whale population's current abundance relative to historic abundance (Reeves et $a l ., 1999)$. The numbers of right whales occurring off Cape Cod in the 1950s-1980s could not possibly have produced the quantities of oil and baleen exported from New England ( $\mathrm{ca} 5,000,000$ US gallons and 1,200,000 pounds, respectively) between 1696-1734.

Several attempts have been made to guess how small the western North Atlantic right whale population was when whaling stopped. S.D. Kraus ('pers. comm.' in Schaeff et al., 1997, p.1075), for example, suggested that it 'may have been reduced to as few as 60 animals'. The context suggests that this estimate refers to some time in the first third of the twentieth century. Kenney et al. (1995) used a simple back-calculation equation and a range of possible annual rates of increase to explore possible numbers for the population in 1935. Using an annual rate of increase of 0.03 
and a 1990 population size of 300, their estimate for 1935 was 58 whales. Preliminary trajectories using known removals and MSY rates of $0.01,0.03$ and 0.05 suggested that the right whale population off the eastern United States had been reduced to very low levels ( $<100$ individuals) several times but was recovering by 1935 (fig. 2 in Reeves et al., 1992). In contrast to these estimates, the comment by Rosenbaum et al. (1997) that 'no recovery is apparent despite six decades of international protection from hunting' implies that there were about 300 whales in the population in the 1930s, as there are today.

Harmer (1928) noted that the right whale 'began to re-appear' in the North Atlantic about 1850 and that by 1880 'it had become the object of a moderate whaling industry off the Eastern United States'. A number of independent sources in the literature refer to a revitalisation of shore-based whaling for right whales in the 1850s at Long Island, New York (Reeves and Mitchell, 1986b) and in the early to mid-1870s in North Carolina (Clark, 1887; Earll, 1887; Reeves and Mitchell, 1988). In addition, a relatively intense episode of pelagic whaling on right whales in the southeastern US began in about 1875 (Reeves and Mitchell, 1986a). A striking feature of this episode was its short duration (1875/76 to $1881 / 82)$ and the low return on effort (e.g. only two right whales were taken in 343 vessel-days by the Golden City and E.H. Hatfield (Reeves and Mitchell, 1986a: their table 3) and the Rising Sun (Taylor, T., 1875-83, $[\mathrm{MS}])^{1}$. As the whaling was conducted in the only known calving ground in the western North Atlantic, it seems clear that the population of reproducing females must have been extremely small by the mid-1880s. In the 1880 s a summer fishery that took mainly fin and humpback whales (Balaenoptera physalus and Megaptera novaeangliae, respectively) was prosecuted in the Gulf of Maine, including the lower Bay of Fundy (Reeves and Barto, 1985). Any right whales encountered in these waters certainly would have been pursued.

Tables 1 and 2 summarise the whaling effort and removals, respectively, for the crucial period 1850-1910. The evident decline in effort and catch in the 1890s and 1900s was not due to market factors because demand for right whale baleen had begun to increase in 1875 and remained strong until 1907 (Bockstoce, 1977). It is clear from numerous sources that by about 1900 right whales were extremely scarce in coastal waters of eastern North America. Dedicated efforts to find and catch them were no longer

1 Taylor, T. 1875-1883 [MS]. Journal of T. Taylor kept aboard the schooner Rising Sun of Provincetown, T.S. Taylor, Master, 27 March 1875-12 September 1883. Phillips Library, Peabody Essex Museum, Salem, MA. economically viable and right whales were chased only opportunistically after the early to mid-1890s. Thus, the western North Atlantic right whale population presumably experienced its most recent 'bottleneck' towards the end of the nineteenth century and into the early twentieth century.

Table 2

Removals of right whales along the Atlantic coast of North America, by decade, 1850-1910. Whales known to have been killed but lost are included as removed; all others struck-but-lost are not included. Numbers in square brackets are estimates; for details, see text of relevant source. Abbreviations as in Table 1. - = no known take.

\begin{tabular}{lcccccc}
\hline & $1850-59$ & $1860-69$ & $1870-79$ & $1880-89$ & $1890-99$ & $1900-10$ \\
\hline MA/RI shore $^{1}$ & 5 & 3 & 1 & 5 & 3 & 1 \\
MA/ME pelagic $^{1}$ & 4 & - & - & 4 & - & - \\
LI shore $^{1,2}$ & 23 & 15 & 18 & 22 & 7 & 5 \\
LI pelagic $^{2}$ & 4 & - & - & - & - & - \\
NJ shore $^{1}$ & - & 2 & 2 & 1 & - & - \\
NC shore $^{3}$ & $1[20+]$ & $1[20+]$ & $10[40+]$ & $3[20+]$ & $6[10]$ & 3 \\
SE US pelagic $^{4}$ & - & - & 5 & $14(+?)$ & - & - \\
Casual SC shore $^{3,4}$ & - & - & - & $2(+?)$ & - & - \\
Unknown $^{5}$ & 1 & - & - & - & - & - \\
TOTALS & $38[57+]$ & $21[40+]$ & $36[66+]$ & $51(+?)[68+]$ & $16[20]$ & 9 \\
\hline
\end{tabular}

References: ${ }^{1}$ Reeves et al. (1999); ${ }^{2}$ Reeves and Mitchell (1986b); ${ }^{3}$ Reeves and Mitchell (1988); ${ }^{4}$ Reeves and Mitchell (1986a); ${ }^{5}$ Wood (no date, MS) indicates that the schooner William Martin of Orleans took a right whale sometime between 26 Dec. 1856 when it sailed from Orleans, and 27 Jan. 1857 when it was at Dominica.

\section{STOCK STRUCTURE AND HISTORIC DISTRIBUTION}

Three hypotheses for stock structure in the North Atlantic have been proposed: (1) a single stock throughout the North Atlantic; (2) two stocks - eastern and western; and (3) three stocks - eastern, central and western (Reeves and Mitchell, 1986a). Gaskin (1991) argued that the right whales summering in the Bay of Fundy and on the Scotian Shelf comprise a deme, or 'separate sub-stock.' This suggestion seems to accommodate some of the puzzling aspects of the catch history, as Gaskin points out, but it presupposes that right whales are much less mobile than they have been shown to be. Long-distance movements by photo-identified individuals have been documented between the Cape Farewell Ground (Fig. 1) and the east coast of North America (Knowlton et al., 1992). Therefore, hypothesis (3) above is probably false but either of the first two could be true.

Patterns of resightings of photo-identified individuals, in combination with patterns of annual visitation to the Bay of Fundy by composite mitochondrial DNA morphs, have been

Effort at taking right whales along the US Atlantic coast, by decade, 1850-1910. ME, Maine; MA, Massachusetts; RI, Rhode Island; LI, Long Island; NJ, New Jersey; NC, North Carolina; SE US, southeastern United States; SC, South Carolina. ? = may have been some effort; - = presumably no effort.

\begin{tabular}{|c|c|c|c|c|c|c|}
\hline & $1850-59$ & $1860-69$ & $1870-79$ & $1880-89$ & $1890-99$ & $1900-10$ \\
\hline Casual MA/RI shore $^{5}$ & Some & Some & Some & Some & Some & Some \\
\hline MA/ME pelagic ${ }^{5,6}$ & Some & Some & $?$ & $\begin{array}{l}1 \text { or more schooners; } 2 \text { or } \\
\text { more steamers; at least } 5 \\
\text { vessel-seasons }\end{array}$ & $?$ & $?$ \\
\hline LI shore ${ }^{4}$ & Many crews & Many crews & Many crews & Many crews & Several crews & Several crews \\
\hline LI pelagic $^{4}$ & $4(+?)$ vessel-seasons & - & - & - & - & - \\
\hline Casual NJ shore 5 & - & Some & Some & Some & - & - \\
\hline NC shore ${ }^{1}$ & $?$ & $?$ & 6-12 crews & 6-18 crews & 5-7 crews & $1-2$ crews \\
\hline SE US pelagic ${ }^{2,3}$ & - & - & 6 vessel-seasons & $14(+?)$ vessel-seasons & - & - \\
\hline Casual SC shore ${ }^{1}$ & $?$ & $?$ & $?$ & Some & $?$ & - \\
\hline
\end{tabular}

References: ${ }^{1}$ Reeves and Mitchell (1988); ${ }^{2}$ Reeves and Mitchell (1986a); ${ }^{3}$ Taylor (1875-1883 MS), see footnote in text above; ${ }^{4}$ Reeves and Mitchell (1986b); ${ }^{5}$ Reeves et al. (1999); ${ }^{6}$ Reeves and Barto (1985). 


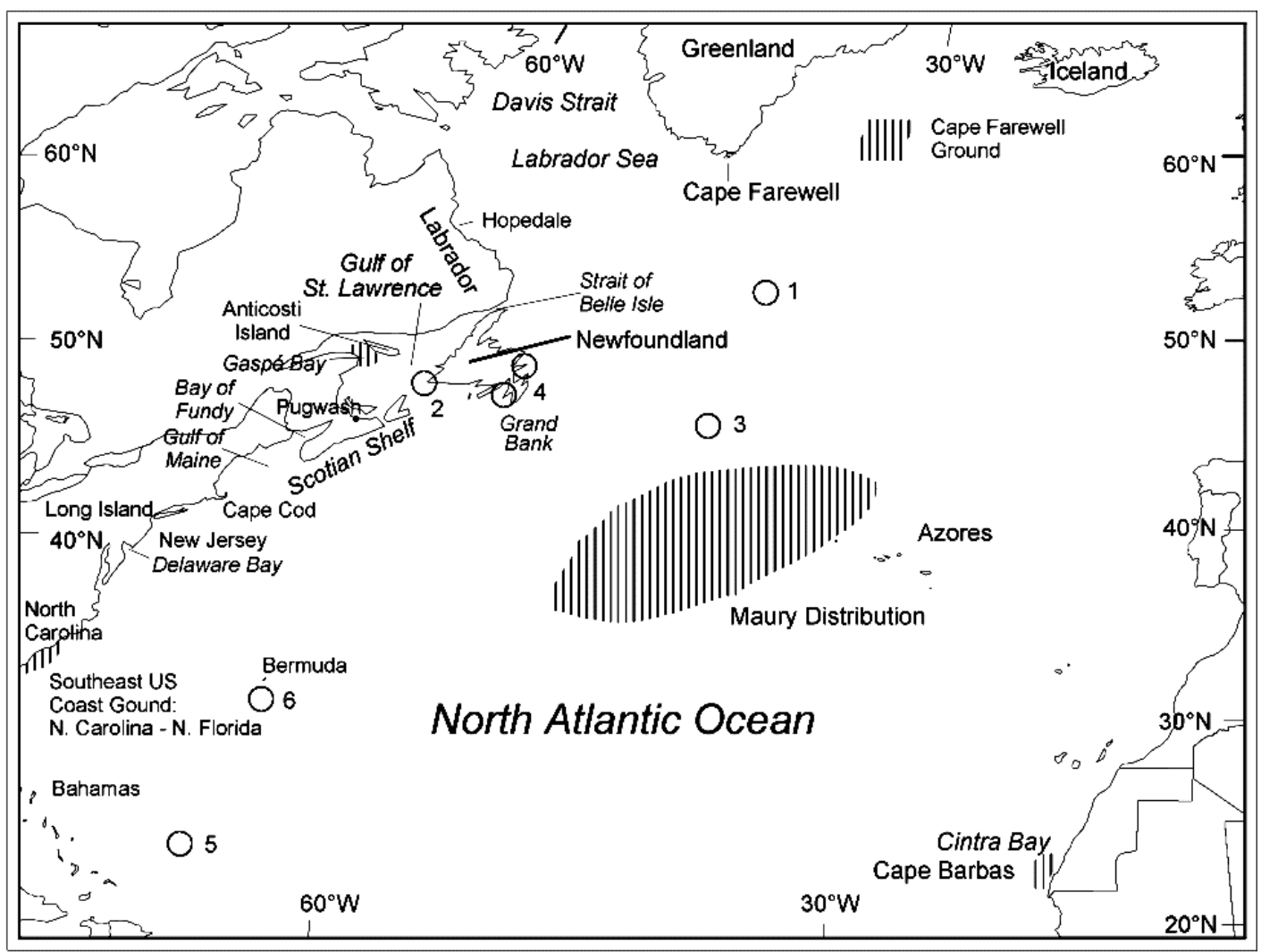

Fig. 1. North Atlantic Ocean, indicating whaling grounds and other areas mentioned in the text. The sightings mentioned in the text are shown as circles, with numbers keyed to text references.

interpreted to mean that the right whales found along the coast between the Scotian Shelf and the southeastern United States represent a single breeding population (Schaeff $e t$ al., 1993). Some structuring within that population, on the basis of relative degrees of philopatry to particular summer 'nursery' areas, was also suggested by these initial analyses.

The following sections briefly consider the state of knowledge about past and current distribution in selected parts of the North Atlantic, including one area in the centre of the basin (Cape Farewell Ground) and one on its east side (Cintra Bay Ground).

\section{Cape Farewell Ground}

This former summer whaling ground for right whales was east of Cape Farewell, Greenland, centred at approximately 60-62 ${ }^{\circ} \mathrm{N}, 33-35^{\circ} \mathrm{W}$ (Schevill and Moore, 1983; Reeves and Mitchell, 1986a). At least a few right whales still migrate to the area (Sigurjónsson et al., 1989; Knowlton et al., 1992). Also, some exchange occurs between this ground and the North American coast: one individual was photographed on the Cape Farewell Ground in early July 1987 and on the Scotian Shelf in mid-June 1989 (Knowlton et al., 1992). The mother and calf seen in early August 1990 at $52^{\circ} 43^{\prime} \mathrm{N}$, 38³6'W (Sigurjónsson et al., 1991; No.1 in Fig. 1) may have been en route to or from the Cape Farewell Ground. Reeves and Mitchell (1986a) reported nineteenth-century sightings by whalers south to $56^{\circ} 10^{\prime} \mathrm{N}$ and west to $43^{\circ} \mathrm{W}$ (see below for further discussion).

\section{Southeast US Coast Ground and alongshore north to Long Island}

The reports of whaling activity alongshore from northern Florida to North Carolina in the winter and spring (Schevill and Moore, 1983; Reeves and Mitchell, 1986a; 1988) are consistent with recent observations that right whales regularly migrate to this area (Kraus et al., 1986). Observations near the North Carolina (Outer Banks) coast are reported less frequently than would be expected judging by the historic shore-based whaling operations there (Reeves and Mitchell, 1988) but this could be due to relatively low sightings effort. The same might be said of the coastal waters of New Jersey (Reeves et al., 1999) and Long Island, New York (Reeves and Mitchell, 1986b).

Mead and Mitchell (1984) suggested that some of the whales hunted in Delaware Bay in the mid-seventeenth century were gray whales (Eschrichtius robustus). While that may be true, right whales certainly occurred there in the late winter and early spring (Lipton, 1975; Reeves et al., 1999). They also moved, at least occasionally, far inside the Bay and into the mouth of the Delaware River (Reeves et al., 1978). The inner parts of Delaware Bay and the river mouth seem not to be used regularly by right whales today. The recent appearance of a right whale about $130 \mathrm{~km}$ up the Delaware River was regarded as an anomaly (Hamilton, 1995). The lack of more observations in Delaware Bay can be interpreted as an indication that the carrying capacity has declined (i.e. this part of their range is no longer suitable habitat), that the population has yet to recover sufficiently to re-occupy all areas of past use (Winn et al., 1986) or that search effort in the Bay during the appropriate season has not been intensive and regular enough to detect right whales other than occasionally.

\section{Newfoundland, Labrador and Gulf of St Lawrence}

Whaling records for these areas have been confounded by the fact that the historic range of bowheads overlapped that of right whales (Moore and Reeves, 1993; Ross, 1993). A substantial proportion of the balaenids killed by commercial whalers in the Strait of Belle Isle apparently were bowheads 
(Cumbaa, 1986). Inuit hunted bowheads in the late autumn (mainly November) along the Labrador coast as far south as Hopedale $\left(55-56^{\circ} \mathrm{N}\right)$ during early historic times (Taylor, 1988). Presumably, the overlap in range was out of phase, such that bowheads moved south along the Labrador coast and into the Strait of Belle Isle in the winter and left in the spring, prior to the arrival of right whales from the south. This would mean that most balaenids taken off Labrador, in the Strait of Belle Isle and in the northeastern Gulf of St Lawrence in summer and autumn months were right whales.

The records of New England whalemen sighting whales in the heavy ice of the Strait of Belle Isle in May and hunting 'right' whales in the northern Labrador Sea and southern Davis Strait in June and July could refer to bowheads (see table 1 in Reeves and Mitchell, 1986a). The balaenids hunted along the Labrador coast in August and in the Gulf of St Lawrence in summer and autumn months (e.g. Wakeham et al., 1913; Mitchell and Reeves, 1983) were more likely right whales than bowheads. Recent observations of right whales in the northwestern Gulf off Gaspé Bay and the west end of Anticosti Island (Lien et al., 1989; Richard Sears, pers. comm., 19 May 1999) are broadly consistent with what is known of the historic distribution. No balaenids have been sighted in recent surveys of the Strait of Belle Isle (Kingsley and Reeves, 1998; M.C.S. Kingsley, pers. comm., May 1999). However, the carcass of a $9 \mathrm{~m}$ female bowhead was found adrift off the northeast coast of Newfoundland $\left(49^{\circ} 40^{\prime} \mathrm{N}, 5^{\circ} 10^{\prime} \mathrm{W}\right)$ in mid-October 1998 (Daoust et al., 1998). This is the first confirmed record of a bowhead in the western North Atlantic south of Hudson Strait in the twentieth century.

The sighting of a right whale off the southwestern coast of Newfoundland in February 1984 (Lien et al., 1989; No. 2 in Fig. 1) seems like an exceptional event according to both historic and modern standards. The only other published record of a right whale in the southeastern Gulf of St Lawrence was a live-stranded animal at Pugwash, Nova Scotia, in October 1954 (Sergeant et al., 1970). Gaskin (1991) suggested that some right whales may not migrate south but instead over-winter in offshore waters with high secondary production, and he recommended that winter surveys be conducted along the northern margins of the Gulf Stream to investigate this possibility. Mate et al. (1992) speculated that copepod concentrations in deep basin waters of the Scotian Shelf could represent an important resource for right whales in the autumn and winter.

\section{Other areas}

New England whalers hunted right whales east of the Grand Bank from July to September in the 1750s-1760s (Reeves and Mitchell, 1986a). The positions given in logbooks suggest that the whales were found off the eastern and northeastern edges of the Grand Bank. These eighteenth century observations probably account for the so-called 'Maury distribution', roughly bounded by $35-43^{\circ} \mathrm{N}$ and 30-49 ${ }^{\circ} \mathrm{W}$ (Maury, 1853; see Reeves and Mitchell, 1986a). Observations of two right whales at $46^{\circ} 37^{\prime} \mathrm{N}, 43^{\circ} 19^{\prime} \mathrm{W}$ on 30 May 1897 (Reeves and Mitchell, 1986a; No. 3 in Fig. 1), the mother and calf at $52^{\circ} 43^{\prime} \mathrm{N}, 38^{\circ} 36^{\prime} \mathrm{W}$ on 5 August 1989 mentioned earlier (Knowlton et al., 1992; No. 1 in Fig. 1) and single individuals off southeastern Newfoundland ( $\mathrm{ca}$ $46^{\circ} 30^{\prime} \mathrm{N}-48^{\circ} 30^{\prime} \mathrm{N}$ ) between mid-July and early September in recent years (Knowlton et al., 1992; No. 4 in Fig. 1) are all consistent with the hypothesis that some right whales disperse far to the east and north of the Scotian Shelf in the late spring and summer. The photographic match of an individual seen off Cape Cod in May 1999 and again in a Norwegian fjord in September 1999 (Øien and Marx, pers. comm., as cited in IWC, 2001 [see p.66, this volume]) demonstrates that right whales sometimes move across the entire North Atlantic Ocean.

Rapid long-distance movements by satellite-monitored right whales provide support to the hypothesis that the northern 'summering' grounds are extensive both latitudinally and longitudinally. An adult male (NEA No.1421) travelled $3,056 \mathrm{~km}$ in 42 days (12 September-24 October 1990), including an excursion offshore to waters 4,200m deep; a mother and calf (mother, NEA No. 1140) covered at least $3,764 \mathrm{~km}$ in 42 days (24 August-5 October 1990), remaining mainly in near-shore waters from the Bay of Fundy to New Jersey (Mate et al., 1997). Another adult female (NEA No.1135), inferred to have been pregnant, was tracked for seven days (24-31 August 1990), moving between the Bay of Fundy and Emerald Basin on the Scotian Shelf and covering at least $779 \mathrm{~km}$ for an average daily speed of $4.6 \mathrm{~km} / \mathrm{hr}$ (Mate et al., 1997). Such mobility makes it easy to imagine that a right whale seen east of the Grand Bank in July or early August could be en route to or from the Cape Farewell Ground, with sufficient time to visit the summer and autumn feeding aggregation areas on the Scotian Shelf and in the Bay of Fundy. Whalers generally tried to arrive on the Cape Farewell Ground by mid-June and most left well before mid-August (Reeves and Mitchell, 1986a: their table 2).

A historical record of right whales in an area far offshore, east of the Bahamas and south of Bermuda, raises an interesting possibility in the ongoing search for one or more additional wintering areas. On 5 April 1870 the New Bedford bark Ansel Gibbs (1869-70, [MS]) $)^{2}$ was en route home from a sperm whaling voyage to the eastern North Atlantic. Two right whales were seen and chased, without success, at $23^{\circ} 58^{\prime} \mathrm{N}, 66^{\circ} 42^{\prime} \mathrm{W}$ (No. 5 in Fig. 1). To my knowledge, this is the only reliable record of right whales from this area although two animals were sighted 25 n.miles southwest of Bermuda on 13 April 1970 (Payne and McVay, 1971; No. 6 in Fig. 1) and another pair was seen in the Gulf of Mexico off Sarasota on 10 March 1963 (Moore, J.C. and Clark, 1963). These sightings, taken together, demonstrate that right whales, at least occasionally, disperse well away from their well-known near-shore wintering grounds between northern Florida and Cape Cod Bay. In my experience reading logbooks of voyages to the North Atlantic, most vessels that were west-bound from the Cape Verde Islands (as was the Ansel Gibbs in 1870) made a landfall at Barbados before heading north to the Bahamas, the Charleston Ground or the Southern Ground in pursuit of sperm whales (Physeter macrocephalus). The Ansel Gibbs did not take this route but angled northwestwards before reaching Barbados. Perhaps this helps to explain why more voyages circumnavigating the North Atlantic in the usual clockwise manner (New England east to the Azores, south to the Cape Verdes, west to the Antilles and north to home) failed to encounter right whales.

\section{The Cintra Bay question}

Schevill and Moore (1983) 'rediscovered' the Cintra Bay Ground where American whalers hunted right whales between 1855-1880 (for details see Reeves and Mitchell, 1986a; 1990). It is clear from the historical record that right

2 Ansel Gibbs. 1869-70 [MS]. Logbook of the bark Ansel Gibbs of New Bedford, Charles Stetson, Master, 20 October 1869-12 May 1870. New Bedford Whaling Museum, New Bedford, MA, Logbook 500B. 
whales, including mothers and calves, visited coastal waters of northwest Africa between Cintra Bay and Cape Barbas during winter months (late November to mid-April). However, in two recent winter surveys (Lamarche and Vely, 1992; Notarbartolo-di-Sciara et al., 1998) no evidence was found to suggest that right whales still use the area. Further investment of research effort in this region probably needs to be justified in some way other than as a search for right whales. The absence of evidence that right whales still visit the Cintra Bay region in the winter is consistent with the rarity of recent observations in European waters to the north (Brown, 1986; Martin and Walker, 1997; Notarbartolo-di-Sciara et al., 1998), assuming that the whales from Cintra Bay traditionally migrated in the late spring and early summer to northern feeding areas off the British Isles, Norway and Iceland as proposed by Thompson (1928) and Brown (1986).

\section{RECONSTRUCTION OF CATCH HISTORY: STATE OF COMPLETION}

With completion of the catch history project for the northeastern United States (Reeves et al., 1999), studies have now covered the entire US coast, including shore whaling at Long Island (Reeves and Mitchell, 1986b) and along the southeastern states (Reeves and Mitchell, 1988), American pelagic whaling (Reeves and Mitchell, 1986a) and the little whaling known to have taken place in the Bay of Fundy (Reeves and Barto, 1985). The only major geographic gap in coverage is the Newfoundland/Gulf of $\mathrm{St}$ Lawrence/Labrador region for which Aguilar (1986) provided valuable information from European archives and Mitchell and Reeves (1983) reviewed some of the literature from North American sources. Using conversion factors for oil production based on data from American shore whaling, and assuming that the catch was half right whales and half bowheads, Reeves et al. (1999) estimated from Barkham's (1984) production data that the sixteenth century Basque whalers may have secured 283-364 right whales in the western North Atlantic in some years. Aguilar (1986) estimated that 300-500 'mainly right whales' were secured annually by the Basques between 1530-1610. These catch levels by the Basques are much higher than the one-year estimates of the catch by shore whalers in the northeastern United States, which ranged only to as high as 158 based on baleen production (in 1724) and 250 on oil production (in 1734 , by which time, however, oil from sperm whales and other species may have been mixed in the returns; Reeves et al., 1999).

The next step, apart from trying to document catches in southeastern Canada in greater detail, is to compile annual removal estimates for all catching areas combined. This will need to include adjustments of catch to account for hunting loss but more importantly will require major interpolations and extrapolations to account for years with little or no documentation.

Estimating historic population levels for right whales in the western North Atlantic poses many challenges. Among them are that: (1) whaling began, and the largest catches were made, long before there was any systematic effort to document catch or production; (2) the period of exploitation was prolonged, lasting from at least the early 1500 s to the early 1900s; (3) stock structure is uncertain; (4) climatic and other environmental variability has had unknown effects on the whales' distribution and seasonal migrations if not also on their abundance and vital rates; and (5) historical factors (e.g. changes in whaling technology, changes in the economic value of oil and baleen) probably influenced whaling effort and efficiency over the period of exploitation.

Given the many uncertainties, especially those related to changes in carrying capacity, there are severe limits on what historical research can provide. Even if one were to set aside concerns about climatic variability and changes in habitat quality, the great uncertainty about removals and stock structure would persist. With new techniques that make it possible to obtain DNA from baleen in museum collections (Rosenbaum et al., 1997) and thus to supplement ongoing biopsy sampling of live and stranded whales, rapid progress towards understanding stock structure should be possible (e.g. see IWC, 2001). However, it is difficult to foresee a similar breakthrough to reduce the uncertainty about removals by whaling in early historic times.

\section{ACKNOWLEDGEMENTS}

I am grateful to Peter Best for bringing to my attention the possibility that the Ansel Gibbs encountered right whales during its $1869-70$ voyage. Peter Barry produced the map figure.

\section{REFERENCES}

Aguilar, A. 1986. A review of old Basque whaling and its effect on the right whales (Eubalaena glacialis) of the North Atlantic. Rep. int. Whal. Commn (special issue) 10:191-9.

Allen, G.M. 1916. The whalebone whales of New England. Mem. Boston Soc. Nat. Hist. 8(2):106-322.

Barkham, S.H. 1984. The Basque whaling establishments in Labrador 1536-1632 - a summary. Arctic 37(4):515-9.

Bockstoce, J.R. 1977. Steam Whaling in the Western Arctic. New Bedford Whaling Museum, New Bedford, MA. 127pp.

Brown, S.G. 1986. Twentieth-century records of right whales (Eubalaena glacialis) in the northeast Atlantic Ocean. Rep. int. Whal. Commn (special issue) 10:121-7.

Clark, A.H. 1887. The whale-fishery. 1. History and present condition of the fishery. Part XV. In: G.B. Goode (ed.), The Fisheries and Fishery Industries of the United States. Sect. V. p.3-218. A geographical review of the fisheries industries and fishing communities for the year 1880. Government Printing Office, Washington, DC. 787pp.

Cumbaa, S.L. 1986. Archaeological evidence of the 16th century Basque right whale fishery in Labrador. Rep. int. Whal. Commn (special issue) 10:187-90

Daoust, P.Y., Lien, J. and Knowlton, A. 1998. Bowhead whale (Balaena mysticetus) stranding on the northeast coast of Newfoundland. Wildlife Health Centre Newsletter 5(3):4-5.

Earll, R.E. 1887. North Carolina and its fisheries. Part XII. In: G.B. Goode (ed.) The Fisheries and Fishery Industries of the United States. Sect. II, p.475-97. A geographical review of the fisheries industries and fishing communities for the year 1880. Government Printing Office, Washington, DC. 787pp.

Gaskin, D.E. 1991. An update on the status of the right whale, Eubalaena glacialis, in Canada. Can. Field-Nat. 105(2):198-205.

Hamilton, P. 1995. A right whale up the Delaware River. Whalewatcher 29(1):8-9.

Harmer, S.F. 1928. The history of whaling. Proc. Linn. Soc. Lond. 140:51-95.

International Whaling Commission. 2001. Report of the Workshop on Status and Trends of Western North Atlantic Right Whales. J. Cetacean Res. Manage. (special issue) 2:61-87.

Kenney, R.D., Winn, H.E. and Macaulay, M.C. 1995. Cetaceans in the Great South Channel, 1979-1989: Right whale (Eubalaena glacialis). Cont. Shelf Res. 15(4-5):385-414.

Kingsley, M.C.S. and Reeves, R.R. 1998. Aerial surveys of cetaceans in the Gulf of St. Lawrence in 1995 and 1996. Can. J. Zool. 76:1529-50.

Knowlton, A.R., Sigurjónsson, J., Ciano, J.N. and Kraus, S.D. 1992. Long-distance movements of North Atlantic right whales (Eubalaena glacialis). Mar. Mammal Sci. 8(4):397-405.

Kraus, S.D., Prescott, J.H., Knowlton, A.R. and Stone, G.S. 1986. Migration and calving of right whales (Eubalaena glacialis) in the 
western North Atlantic. Rep. int. Whal. Commn (special issue) 10:139-44.

Lamarche, B. and Vely, M. 1992. Rapport sur une prospection aérienne de la côte du Sahara Occidental, de Nouadhibou à Dakhla (trajet aller et retour de 31 Janvier 1992). Unpublished report. [In French]. $7 \mathrm{pp}$.

Lien, J., Sears, R., Stenson, G.B., Jones, P.W. and Ni, I.-H. 1989. Right whale, Eubalaena glacialis, sightings in waters off Newfoundland and Labrador and the Gulf of St. Lawrence, 1978-1987. Can. Field-Nat. 103(1):91-3.

Lipton, B. 1975. Whaling days in New Jersey. Newark Mus. Quart. 26(2-3):72p.

Martin, A.R. and Walker, F.J. 1997. Sighting of a right whale (Eubalaena glacialis) with calf off S.W. Portugal. Mar. Mammal Sci. 13(1):139-40.

Mate, B.R., Nieukirk, S., Mesecar, R. and Martin, T. 1992. Application of remote sensing methods for tracking large cetaceans: North Atlantic right whales (Eubalaena glacialis). Final report by Oregon State University to the US Department of the Interior, Minerals Management Service, Alaska and Atlantic OCS Regional Offices. OCS Study MMS 91-0069. 167pp.

Mate, B.R., Nieukirk, S.L. and Kraus, S.D. 1997. Satellite-monitored movements of the northern right whale. J. Wildl. Manage. 61(4):1393-405.

Maury, M.F. 1853. A chart showing the favourite resort of the sperm and right whale by M.F. Maury, LLD Lieut. US Navy. Constructed from Maury's whale chart of the world, by Robt H. Wyman, Lieut. USN by Authority of Commo: Charles Morris USN Chief of Bureau of Ordnance and Hydrography. Washington, 1 sheet.

Mead, J.G. 1986. Twentieth-century records of right whales (Eubalaena glacialis) in the northwestern Atlantic Ocean. Rep. int. Whal. Commn (special issue) 10:109-19.

Mead, J.G. and Mitchell, E.D. 1984. Atlantic gray whales. pp. 33-53. In: M.L. Jones, S.L. Swartz and S. Leatherwood (eds.) The Gray Whale Eschrichtius robustus. Academic Press, Orlando, FL. xxiv+600pp.

Mitchell, E. and Reeves, R.R. 1983. Catch history, abundance, and present status of northwest Atlantic humpback whales. Rep. int. Whal. Commn (special issue) 5:153-212.

Mitchell, E.D., Kozicki, V.M. and Reeves, R.R. 1986. Sightings of right whales, Eubalaena glacialis, on the Scotian Shelf, 1966-1972. Rep. int. Whal. Commn (special issue) 10:83-107.

Moore, J.C. and Clark, E. 1963. Discovery of right whales in the Gulf of Mexico. Science 141:269.

Moore, S.E. and Reeves, R.R. 1993. Distribution and movement. pp. 313-86. In: J.J. Burns, J.J. Montague and C.J. Cowles (eds.) The Bowhead Whale. Special Publication No. 2. Society for Marine Mammalogy, Lawrence, KS. 787pp.

National Marine Fisheries Service. 1991. Recovery plan for the northern right whale (Eubalaena glacialis). Prepared by the Right Whale Recovery Team for the NMFS, 1335 East-West Highway, Silver Spring, MD 20910, USA. vi+86pp.

Notarbartolo-di-Sciara, G., Politi, E., Bayed, A., Beaubrun, P.-C. and Knowlton, A. 1998. A winter cetacean survey off southern Morocco, with a special emphasis on right whales. Rep. int. Whal. Commn 48:547-50.

Payne, R. and McVay, S. 1971. Songs of humpback whales. Science 173:585-97.

Reeves, R.R. 1991. Pre-exploitation abundance of right whales. Whalewatcher 25(3):3-5.

Reeves, R.R. and Barto, M.F. 1985. Whaling in the Bay of Fundy. Whalewatcher 19(4):14-8.

Reeves, R.R. and Mitchell, E. 1986a. American pelagic whaling for right whales in the North Atlantic. Rep. int. Whal. Commn (special issue) $10: 221-54$.
Reeves, R.R. and Mitchell, E. 1986b. The Long Island, New York, right whale fishery: 1650-1924. Rep. int. Whal. Commn (special issue) 10:201-20.

Reeves, R.R. and Mitchell, E. 1988. History of whaling in and near North Carolina. NOAA Tech. Rep. NMFS 65. iii+28pp.

Reeves, R.R. and Mitchell, E. 1990. Right whales, not humpbacks, taken in Cintra Bay. Am. Neptune 50(2):119-26.

Reeves, R.R., Mead, J.G. and Katona, S. 1978. The right whale, Eubalaena glacialis, in the western North Atlantic. Rep. int. Whal. Commn 28:303-12.

Reeves, R.R., Breiwick, J.M. and Mitchell, E.D. 1992. Pre-exploitation abundance of right whales off the eastern United States. pp. 5-7. In: The right whale in the western North Atlantic: a Science and Management Workshop, 14-15 April 1992, Silver Spring, Maryland. NOAA/NMFS, Northeast Fisheries Science Center Reference Document 92-05.

Reeves, R.R., Breiwick, J.M. and Mitchell, E. 1999. History of whaling and estimated kill of right whales, Balaena glacialis, in the northeastern United States, 1620-1924. Mar. Fish. Rev. 61(3):1-36.

Rosenbaum, H.C., Egan, M.G., Clapham, P.J., Brownell Jr, R.L. and DeSalle, R. 1997. An effective method for isolating DNA from historical specimens of baleen. Mol. Ecol. 6:677-81.

Ross, W.G. 1993. Commercial whaling in the North Atlantic sector. pp. 511-61. In: J.J. Burns, J.J. Montague and C.J. Cowles (eds.) The Bowhead Whale. Special Publication No. 2. Society of Marine Mammalogy, Lawrence, KS. 787pp.

Schaeff, C.M., Kraus, S.D., Brown, M.W. and White, B.N. 1993. Assessment of the population structure of western North Atlantic right whales (Eubalaena glacialis) based on sighting and mtDNA data. Can. J. Zool. 71(2):339-45.

Schaeff, C.M., Kraus, S.D., Brown, M.W., Perkins, J.S., Payne, R. and White, B.N. 1997. Comparison of genetic variability of North and South Atlantic right whale (Eubalaena), using DNA fingerprinting. Can. J. Zool. 75:1073-80.

Schevill, W.E. and Moore, K.E. 1983. Townsend's unmapped North Atlantic right whales (Eubalaena glacialis). Breviora 476:1-8.

Schevill, W.E., Watkins, W.A. and Moore, K.E. 1986. Status of Eubalaena glacialis off Cape Cod. Rep. int. Whal. Commn (special issue) $10: 79-82$.

Sergeant, D.E., Mansfield, A.W. and Beck, B. 1970. Inshore records of Cetacea for eastern Canada, 1949-68. J. Fish. Res. Bd Can. 27(11):1903-15.

Sigurjónsson, J., Gunnlaugsson, T. and Payne, M. 1989. NASS-87: Shipboard sightings surveys in Icelandic and adjacent waters June-July 1987. Rep. int. Whal. Commn 39:395-409.

Sigurjónsson, J., Gunnlaugsson, T., Ensor, P., Newcomer, M. and Víkingsson, G. 1991. North Atlantic Sightings Survey 1989 (NASS-89): shipboard surveys in Icelandic and adjacent waters July-August 1989. Rep. int. Whal. Commn 41:559-72.

Taylor, J.G. 1988. Labrador Inuit whale use during the early contact period. Arct. Anthropol. 25(1):120-30.

Thompson, D.W. 1928. On whales landed at the Scottish whaling stations during the years 1908-1914 and 1920-1927. Fish. Board Scotl. Sci. Invest. 3:3-39.

Wakeham, W., Bernard, C.A. and Riendeau, J. 1913. Appendix No. 6 Quebec. pp. 221-53. In: Forty-sixth Annual Report of the Department of Marine and Fisheries, 1912-13 Fisheries. Canadian Department of Marine and Fisheries, Ottawa.

Winn, H.E., Price, C.A. and Sorensen, P.W. 1986. The distributional biology of the right whale (Eubalaena glacialis) in the western North Atlantic. Rep. int. Whal. Commn (special issue) 10:129-38.

Wood, D. No date [MS]. Abstracts of whaling voyages [1835-75]. 5 vols. New Bedford Free Public Library, New Bedford, MA. 